\title{
EFFECT OF MOZART MUSIC THERAPY ON THE SUCKING REFLEX AND BODY WEIGHT GAIN IN INFANTS WITH LOW BIRTH WEIGHT
}

\author{
Anggun Fitri Handayani'), Maftuchah²), Hermeksi Rahayu²) \\ 1)Masters Program in Public Health, Universitas Sebelas Maret \\ 2)Undergraduate Applied of Midwifery Science Program, Universitas Karya Husada
}

\begin{abstract}
Background: Music, with its elements, sounds, rhythms, melody and harmony, works as an intermediate object of a relationship that enables the development of a therapeutic process. It may influence both physiological and behavioral aspects. Studies with premature infants report its influence on the reduction in heart and respiratory rates, cortisol levels, and behavioral states of stress, with an increase in oxygen saturation, in the velocity of non-nutritive sucking, and in weight gain, thus reducing hospitalization time. This study aimed to examine effect of mozart music therapy on the sucking reflex and low birth weight.
\end{abstract}

Subjects and Method: A quasy experiment with no control group was carried out at K.R.M.T Wongsonegoro hospital. A sample of 14 low birth weight infants was selected by accidental sampling. The dependent variables were sucking reflex and bdy weight gain. The independent variable was mozart classic music. The fetus is played classical music using tape recorder for 30 minutes everyday in a month. Infant body weight was measured by infant weight scale. Sucking reflex was measured by observation. Mean difference of sucking reflex and body weight gain before and after intervention were measured by paired t-test.

Results: Sucking reflex after Mozart therapy (Mean=1.71; $\mathrm{SD}=0.26$ ) was higher than before (Mean=1.07; $\mathrm{SD}=0.46)$ and it was statistically significant $(\mathrm{p}<0.001)$. Body weight after Mozart therapy (Mean= 2,400.64; $\mathrm{SD}=96.5$ ) was higher than before (Mean= 2,280.71; $\mathrm{SD}=108.60)$ and it was statistically significant $(\mathrm{p}<0.001)$.

Conclusion: Mozart therapy increases sucking reflex and body weight in infants with low birth weight.

Keyword: sucking reflex, body weight, mozart classic music, infants

\section{Correspondence:}

Anggun Fitri Handayani. Masters Program in Public Health. Jl. Ir. Sutami 36A, Surakarta 57126, Central Java. Email: Handayanianggun22@gmail.com. Mobile: +6281225095742. 